\title{
Microbial etiology of neonatal conjunctivitis in a hospital in the city of Medellín
}

\section{Etiología microbiana de la conjuntivitis neonatal en un hospital de la ciudad de Medellín}

\author{
Martha L. Gaviria-Bravo ${ }^{1,2,3 *}$, Yenny Llano-Naranjo ${ }^{1}$ and Oscar A. Villada-Ochoa ${ }^{4}$ \\ ${ }^{1}$ Department of Ophthalmology, University of Antioquia, Medellin; ${ }^{2}$ Division of Pediatric Ophthalmology and Strabismus, Santander Ophthalmology \\ Foundation, Santander; ${ }^{3}$ Department of Ophthalmopediatrics, Hospital Universitario San Vicente Fundación, Medellín; ${ }^{4}$ Research Directorate, \\ Hospital Universitario San Vicente Fundación, Medellín. Colombia
}

\begin{abstract}
Objective: To describe the microbial etiology, maternal risk factors and antibiotic sensitivity of neonatal conjunctivitis at San Vicente Hospital Foundation in Medellín since 2012-2018. Methodology: A descriptive, ambispective trial was carried out between January 2012 and November 2018. We reviewed the medical records of patients diagnosed with neonatal bacterial conjunctivitis with positive cultures of conjunctival secretion. Sociodemographic variables of the mother and the neonate, associated risk factors, results of the microbiological isolations, topical and systemic antibiotic therapy and antibiotic sensitivity were recorded. Results: $A$ total of 69 newborns were identified, $65.22 \%$ were male, the average age was $15.7 \pm 8.3$ days. Major etiological agents identified were Staphylococcus epidermidis ( $n=20,28.9 \%)$, Staphylococcus aureus $(n=12,17.3 \%)$ and Haemophilus influenzae (9 patients, 13.0\%). There were no positive isolates for Chlamydia trachomatis or Neisseria gonorrhoeae. The most common maternal peripartum risk factors were premature rupture of the ovular membranes $(n=16$, $21.33 \%$ ), urinary tract infection (7 cases, $10.1 \%)$, preterm birth syndrome $(n=6,8.00 \%)$ and bacterial vaginosis (5 cases, $7.25 \%)$. Resistance to oxacillin $26 \%(n=18)$ and tetracyclines $15 \%(n=11)$ was observed in patients with Staphylococcus infection. Conclusion: Over the years, the epidemiology of neonatal conjunctivitis has changed. Nowadays, gonococcal pathogens are not the most common cause of neonatal conjunctivitis. A significant number of patients with methicillin-resistant $S$. aureus were observed.
\end{abstract}

Key words: Neonatal conjunctivitis. Risk factors. Culture. Bacteria.

\section{Resumen}

Objetivo: Describir la etiología microbiana, factores de riesgo asociados y sensibilidad antibiótica de la conjuntivitis neonatal en el Hospital Universitario San Vicente Fundación de Medellín en el periodo de 2012 a 2018. Metodología: Estudio descriptivo, ambispectivo, desde enero de 2012 a noviembre de 2018 en donde se revisaron las historias clínicas de pacientes con diagnóstico de conjuntivitis neonatal con resultados de cultivos positivos de secreción conjuntival en un hospital de tercer nivel en la ciudad de Medellín. Se estudiaron variables sociodemográficas de la madre y el neonato, factores de riesgo asociados, resultados de los aislamientos microbiológicos, terapia antibiótica tópica y sistémica y sensibilidad antibiótica. Resultados: Se identificaron un total de 69 neonatos, $65.22 \%$ de sexo masculino, con una edad media de $15.7 \pm 8.3$ días. Los

Correspondence:

*Martha L. Gaviria Bravo

Hosp. Univ. San Vicente Fundación Date of reception: 31-08-2019

C. 64 No 51 D 154, Medellín, Colombia Date of acceptance: 07-11-2019

E-mail: mlgaviriabravo@gmail.com DOI: 10.24875/RMOE.M20000104

Available online: 01-03-2020

Rev Mex Oftalmol (Eng). 2020;94(2):50-56

www.rmo.com.mx

2604-1731/@ 2019 Sociedad Mexicana de Oftalmología. Published by Permanyer. This is an open access article under the CC BY-NC-ND license (http://creativecommons.org/licenses/by-nc-nd/4.0/). 
principales agentes etiológicos encontrados fueron Staphylococcus epidermidis (20 pacientes, 28.9\%), Staphylococcus aureus (12 pacientes, 17.3\%) y Haemophilus influenzae (9 pacientes, 13.0\%). Con las pruebas realizadas no se obtuvo crecimiento para Neisseria gonorrhoeae, ni hubo resultado positivo para Chlamydia trachomatis. Los factores de riesgo maternos periparto encontrados con mayor frecuencia fueron: la ruptura prematura de membranas ovulares ( $n=16,21.33 \%$ ), infección del tracto urinario $(n=7,10.1 \%)$, síndrome de parto pretérmino $(n=6,8.00 \%)$ y vulvovaginitis $(n=5,7.25 \%)$. Para la familia de Staphylococcus se encontró resistencia a la oxacilina del $26 \%(n=18)$ y del $15 \%(n=11)$ a las tetraciclinas. Conclusion: El perfil epidemiológico de la conjuntivitis neonatal ha cambiado en la última década. Actualmente la causa más frecuente son agentes no gonocócicos. Se encontró un importante número de pacientes con Staphylococcus aureus meticilinorresistente.

Palabras clave: Conjuntivitis neonatal. Factores de riesgo. Cultivo. Bacterias.

\section{Introduction}

Neonatal conjunctivitis (NC) is an acute infection of the conjunctival membrane frequent in newborns, which, if left untreated, carries the risk of visual loss ${ }^{1-3}$. The prevalence ranges from 1.6 to $11.3 \%{ }^{4}$, increases in developing countries and causes blindness in about 10,000 infants per year. Of them, half live in the African continent ${ }^{2,5}$.

The cause of NC may be infectious or non-infectious. Within the first group, in the twentieth century, before the widespread use of ocular prophylaxis, Chlamydia trachomatis and Neisseria gonorrhoeae, microorganisms related to sexually transmitted infections, were the main etiological agents ${ }^{6}$. Recently published studies continue to report $\mathrm{C}$. trachomatis as an important cause of NC in some developing countries ${ }^{7,8}$, but to a lesser extent compared to the past.

Currently, in different studies on the epidemiology of NC, bacterial agents of the skin flora and the environment (Staphylococcus sp.), that is, non-gonococcal bacteria, are most the most frequent isolates in conjunctival secretion cultures ${ }^{2,9,10}$.

This change in the epidemiology of $\mathrm{NC}$ is due to the introduction of ocular prophylaxis in the newborn (NB), improvements in the quality of maternal care programs, childbirth programs and timely treatments ${ }^{11,12}$. In regions where these improvements are not implemented, the prevalence of microorganisms of genitourinary origin remains high $^{3}$.

There are few studies on the microbial etiology of NC at the local level, and the existent ones have been published more than a decade ago ${ }^{13,14}$. For these reasons, we conducted this work with the objective of establishing the main causative agents, their antibiotic sensitivity and possible associated risk factors.

\section{Materials and methods}

An observational, descriptive, ambispective, twophase study was conducted on the total number of patients with a diagnosis of NC treated at the Hospital Universitario de San Vicente Fundación, in Medellin, Colombia, between January 2012 and December 2017 (retrospective phase) and between January and November 2018 (prospective phase). Inclusion criteria were a clinical diagnosis of NC, age below 30 days, with positive cultures of conjunctival secretion and a with a record of the results of antibiotic sensitivity available for each culture. Patients diagnosed with dacryostenosis, preseptal cellulitis, or keratoconjunctivitis were excluded.

The following sociodemographic variables of the mother and the NB (age, gender, origin), of the mother (delivery, associated peripartum infections, number of prenatal controls, noninfectious peripartum complications) and of the NB (culture for aerobic bacteria in blood agar and chocolate agar, antigen detection for $\mathrm{C}$. trachomatis and special culture in Thayer Martin medium for N. gonorrheae, presence of dacryostenosis or other associated eye disease, concomitant systemic disease, peripartum risk factors in the mother, type of topic and systemic antibiotic therapy administered in the neonate and antibiotic sensitivity).

Information on the results of positive conjunctival secretion cultures was provided by the clinical laboratory of the Hospital Universitario de San Vicente Fundación. Information on the demographic and clinical variables was extracted from the electronic medical records of the patients contained in the SAP operating system of the Hospital Universitario de San Vicente Fundación.

For information processing, a database was created in Microsoft Excel Office $365^{\circledR}$ (Vermont, USA) with the mentioned variables. Statistical analysis was carried out with the R software. Qualitative variables are described with absolute and relative frequencies for each category. Quantitative variables were evaluated with a normal distribution using the Kolmogorov Smirnov test. The variables with normal distribution are described with means and standard deviations. All researchers participated in the preparation and approval of the final 
document. The research was approved by the Ethics Committee of the Hospital Universitario de San Vicente Fundación and the University of Antioquia.

\section{Results}

\section{Demographic variables}

Between January 2012 and November 2018, we reviewed 106 clinical histories of neonates with a clinical diagnosis of NC and positive conjunctival secretion cultures. In 24 cases (22\%) there was a diagnosis of dacryostenosis and in $3(2.8 \%)$ of periorbital cellulitis, so they were excluded from the analysis. There were 10 patients with an age over 30 days old who did not meet the definition of NC, so they were not included in the study. Finally, a total of 69 patients were included in the analysis, $45(65.2 \%)$ were male and $24(34.78 \%)$ female. Demographic characteristics are summarized in table 1.

Deliveries were classified as $75.3 \%(n=52)$ vaginal deliveries and $24.6 \%(n=17)$ caesarean sections. The majority of these patients were diagnosed in the emergency room $(n=41,59.2 \%)$, neonatal intensive care unit $(n=14,20.2 \%)$ and general pediatric departments $(n=11,15.9 \%)$. All patients received in-hospital management.

The presence of a genitourinary infection associated with the peripartum period in mothers of the NBs was evaluated, and urinary tract infection (UTI) was found in $10.4 \%(n=7)$, followed by vulvovaginitis in $7.25 \%$ $(n=5)$ and positive screening for S. agalactiae in 5.8\% $(n=4) . \ln 44.93 \%(n=31)$ of the cases, there was no report of genitourinary infections associated with the peripartum period.

Peripartum complications in mothers and their correlation with neonates who developed NC were studied, and it was determined that premature rupture of the ovular membranes (PROM) ( $n=16,21.3 \%)$, preterm birth syndrome (PBS) $(n=6,8 \%)$ and, to a lesser extent, hypertensive disorder associated with pregnancy (HDAP) $(n=4,5.3 \%)$ were the most frequent factors (Table 1).

When conducting this study at a third level of complexity, a significant number of NBs presented a systemic disease in addition to NC ( $n=40,69.6 \%)$. Of these systemic diseases, sepsis $(n=18,23 \%)$, followed by bronchiolitis $(n=14,18 \%)$ and pneumonia $(n=10$, $13 \%)$ were the most frequent. In $30.4 \%(n=21)$ no systemic infection was found. Recording the presence of systemic disease was relevant to determine the type
Table 1. Demographic variables $(n=69)$

\begin{tabular}{|c|c|c|}
\hline Variable & n & $\%$ \\
\hline Newborn's age (days)* & \multicolumn{2}{|c|}{$15 \pm 8.3$} \\
\hline $\begin{array}{l}\text { Newborn's genre } \\
\text { Male } \\
\text { Female }\end{array}$ & $\begin{array}{l}45 \\
24\end{array}$ & $\begin{array}{l}65.2 \\
34.8\end{array}$ \\
\hline $\begin{array}{l}\text { Mother's provenience } \\
\text { Urban } \\
\text { Rural } \\
\text { Not registered }\end{array}$ & $\begin{array}{c}32 \\
35 \\
2\end{array}$ & $\begin{array}{c}46.4 \\
50.7 \\
2.9\end{array}$ \\
\hline Mother's gestational age (weeks)* & \multicolumn{2}{|c|}{$35 \pm 4.8$} \\
\hline Number of prenatal controls* & \multicolumn{2}{|c|}{$5.3 \pm 3.2$} \\
\hline $\begin{array}{l}\text { Delivery type } \\
\text { Vaginal } \\
\text { Caesarean section }\end{array}$ & $\begin{array}{l}52 \\
17\end{array}$ & $\begin{array}{l}75.4 \\
24.6\end{array}$ \\
\hline $\begin{array}{l}\text { Newborn care and diagnosis services } \\
\text { Pediatric emergencies } \\
\text { General hospitalization rooms } \\
\text { NICU } \\
\text { NSCU }\end{array}$ & $\begin{array}{l}41 \\
11 \\
14 \\
3\end{array}$ & $\begin{array}{c}59.4 \\
15.9 \\
20.3 \\
4.4\end{array}$ \\
\hline $\begin{array}{l}\text { Genitourinary infection in the mother } \\
\text { None } \\
\text { UTI } \\
\text { Vulvovaginitis } \\
\text { Streptococcus agalactiae }\end{array}$ & $\begin{array}{l}31 \\
7 \\
5 \\
4\end{array}$ & $\begin{array}{l}44.9 \\
10.1 \\
7.3 \\
5.8\end{array}$ \\
\hline $\begin{array}{l}\text { Peripartum complications } \\
\text { None } \\
\text { PROM } \\
\text { PBS } \\
\text { HDAP }\end{array}$ & $\begin{array}{l}44 \\
16 \\
6 \\
4\end{array}$ & $\begin{array}{r}58.7 \\
21.3 \\
8.0 \\
5.3\end{array}$ \\
\hline $\begin{array}{l}\text { Patients with NC with and without } \\
\text { systemic disease } \\
\text { No systemic disease (infants with NC } \\
\text { only) } \\
\text { With associated systemic disease }\end{array}$ & 21 & 30.4 \\
\hline
\end{tabular}

*Average \pm standard deviation

NC: neonatal conjunctivitis; UTI: urinary tract infection; PROM: premature rupture of ovular membranes; PBS: preterm birth syndrome; HDAP. hypertensive disorder associated with pregnancy; NSCU: neonatal special care unit; NICU: neonatal intensive care unit.

of systemic antibiotic therapy received in these patients, compared to those who only had a diagnosis of NC. This will be discussed later in the treatment section (Table 2).

\section{Microbiological findings}

The most frequently found microorganisms were Staphylococcus epidermidis ( $n=20,28.99 \%$ ), followed by Staphylococcus aureus ( $n=12,17.39 \%)$ and Haemophilus influenzae $(n=9,13.04 \%)$. With the tests performed, no growth of $\mathrm{N}$. gonorrhoeae was obtained, and there were no positive results for 
Table 2. Associated systemic disease in the newborn $(\mathrm{n}=69)^{*}$

\begin{tabular}{|l|c|c|}
\hline Systemic disease in the newborn & n & $\%$ \\
\hline None & 21 & 30.4 \\
\hline Sepsis & 18 & 25 \\
\hline Bronchiolitis & 14 & 19 \\
\hline Pneumonia & 10 & 13.3 \\
\hline Respiratory distress & 7 & 9.7 \\
\hline Meningoencephalitis & 1 & 1.3 \\
\hline Otitis & 1 & 1.3 \\
\hline Total & 72 & 100 \\
\hline *A patient could have more than one associated systemic disease. & \\
\hline
\end{tabular}

C. trachomatis. In eight cases (11.54\%) a polymicrobial infection was found. All samples were evaluated in blood agar and chocolate agar $(n=69), 90 \%$ of the samples $(n=62)$ were tested for $C$. thracomatis antigen, and $60 \%(n=41)$ were evaluated in Thayer Martin medium. Table 3 shows a summary of the isolated microorganisms.

When evaluating the type of isolated microorganisms according to the peripartum infection reported in the mother, it was found that urinary tract infection, followed by vulvovaginitis, was the most frequent infection in the mothers of neonates with NC secondary to $\mathrm{S}$. epidermidis and S. aureus. Peripartum complications were also evaluated regarding these microorganisms, and PROM and PBS were the most frequent ones. These were the most frequently detected risk factors, and although a causal relationship cannot be established, it could be considered as a predisposing factor (Table 4).

\section{Topical and systemic antibiotic therapy}

The systemic antibiotic therapy administered more frequently was ampicillin. It was used in $29 \%$ of cases ( $n=29)$, followed by amikacin $(n=18,18 \%)$ and ampicillin/amikacin ( $n=14,14 \%$ ). The most commonly prescribed topical antibiotic was sulfacetamide in $67 \%$ of cases $(n=46)$, gentamicin in $23 \%(n=16)$ of cases and ciprofloxacin in $4 \%$ of cases $(n=3)$. These reported results were in patients who had a systemic disease concomitant with NC. Likewise, the systemic treatment administered in patients with $\mathrm{NC}$ without the presence of systemic disease was evaluated, and the combination of azithromycin and ceftriaxone was
Table 3. Frequency of isolated microorganisms in conjunctival secretion samples of newborns

\begin{tabular}{|l|l|l|}
\hline Microorganism & n & $\%$ \\
\hline Staphylococcus epidermidis & 20 & 28.99 \\
\hline Staphylococcus aureus & 12 & 17.39 \\
\hline Haemophilus influenzae & 9 & 13.04 \\
\hline Staphylococcus hominis & 5 & 7.25 \\
\hline Escherichia coli & 4 & 5.80 \\
\hline Serratia marcescens & 4 & 5.80 \\
\hline Staphylococcus haemolyticus & 3 & 4.35 \\
\hline Streptococcus pneumoniae & 3 & 4.35 \\
\hline Klebsiella pneumoniae & 2 & 2.90 \\
\hline Enterobacter cloacae & 1 & 1.45 \\
\hline Klebsiella oxytoca & 1 & 1.45 \\
\hline Coagulase-negative staphylococci & 1 & 1.45 \\
\hline Staphylococcus sciuri & 1 & 1.45 \\
\hline Staphylococcus warneri & 1 & 1.45 \\
\hline Stenotrophomonas maltophila & 1 & 1.45 \\
\hline Streptococcus vestibularis & 1 & 1.45 \\
\hline Chlamydia trachomatis & 0 & 0 \\
\hline Neisseria gonorrhoeae & 0 & 0 \\
\hline & 69 & 100 \\
\hline Total & 1 & \\
\hline & 1 & 0 \\
\hline
\end{tabular}

the most frequent $(33 \%, n=7)$. In patients without associated systemic disease, sodium sulfacetamide was also the most commonly prescribed topical antibiotic (Tables 5, 6 and 7).

The antibiotic resistance profile was analyzed for all isolated microorganisms. Most microorganisms showed no antibiotic resistance. However, for the Staphylococcus family, there was oxacillin resistance in $26 \%$ $(n=18)$, and tetracycline resistance in $15 \%(n=11)$, indicating a significant number of patients with meticillin-resistant Staphylococcus aureus.

\section{Discussion}

$\mathrm{NC}$ is the most common inflammation of the conjunctiva in the newborn. It is caused in most cases by infectious agents and represents one of the main causes of preventable blindness in the first month of life ${ }^{15,16}$, especially in developing countries where there are deficiencies in the quality of maternal and newborn care, 
Table 4. Microorganisms related to peripartum risk factors

\begin{tabular}{|c|c|}
\hline Maternal infection & Isolated microorganisms \\
\hline None, $\mathrm{n}=31$ & $\begin{array}{l}\text { Staphylococcus epidermidis }(\mathrm{n}=9) \\
\text { Staphylococcus aureus }(\mathrm{n}=5)\end{array}$ \\
\hline Urinary infection, $\mathrm{n}=7$ & Staphylococcus epidermidis $(\mathrm{n}=2)$ \\
\hline Vulvovaginitis, $n=5$ & Staphylococcus epidermidis $(\mathrm{n}=1)$ \\
\hline $\begin{array}{l}\text { Streptococcus } \\
\text { agalactiae, } \mathrm{n}=4\end{array}$ & Staphylococcus epidermidis $(\mathrm{n}=1)$ \\
\hline \multicolumn{2}{|c|}{ Non-infectious maternal complication } \\
\hline None, $\mathrm{n}=42$ & $\begin{array}{l}\text { Staphylococcus epidermidis }(n=17) \\
\text { Haemophilus influenzae }(n=6)\end{array}$ \\
\hline $\begin{array}{l}\text { Premature rupture of } \\
\text { membranes, } n=16\end{array}$ & $\begin{array}{l}\text { Staphylococcus epidermidis }(\mathrm{n}=3) \\
\text { Staphylococcus aureus }(\mathrm{n}=3)\end{array}$ \\
\hline $\begin{array}{l}\text { Preterm birth syndrome, } \\
n=6\end{array}$ & $\begin{array}{l}\text { Staphylococcus aureus }(\mathrm{n}=2) \\
\text { Staphylococcus hominis }(\mathrm{n}=2)\end{array}$ \\
\hline $\begin{array}{l}\text { Hypertensive disorder, } \\
\mathrm{n}=4\end{array}$ & Staphylococcus aureus $(\mathrm{n}=3)$ \\
\hline \multicolumn{2}{|l|}{ Neonatal infection } \\
\hline None, $\mathrm{n}=27$ & $\begin{array}{l}\text { Staphylococcus epidermidis }(\mathrm{n}=11) \\
\text { Escherichia coli }(\mathrm{n}=3)\end{array}$ \\
\hline Sepsis, $n=14$ & $\begin{array}{l}\text { Staphylococcus aureus }(\mathrm{n}=5) \\
\text { Staphylococcus epidermidis }(\mathrm{n}=4)\end{array}$ \\
\hline Bronchiolitis, $n=18$ & $\begin{array}{l}\text { Haemophilus influenzae }(\mathrm{n}=8) \\
\text { Staphylococcus aureus }(\mathrm{n}=4)\end{array}$ \\
\hline Pneumonia, $\mathrm{n}=10$ & $\begin{array}{l}\text { Staphylococcus epidermidis }(\mathrm{n}=3) \\
\text { Haemophilus influenzae }(\mathrm{n}=2)\end{array}$ \\
\hline
\end{tabular}

so it clearly remains a serious and relevant condition ${ }^{17}$ for this population. The type of microorganism, risk of infection and prevalence vary by geographical area, delivery conditions and applied prophylactic topical treatment ${ }^{18,19}$.

In the 1970s, NC was mainly caused by microorganisms associated with sexually transmitted infections acquired through the birth canal ${ }^{16,17}$. N. gonorrhoeae was reported in up to $50 \%$ of the cases ${ }^{21,22}$, and, secondly, C. trachomatis. In a study conducted in South Korea, they reported a cumulative prevalence of gonococcal NC in decline, $25 \%$ in $1982,9 \%$ in 1991 and $0.9 \%$ in $1997^{23}$.

Regarding chlamydia, although its prevalence has decreased, it has not been parallel to that of gonococcus $^{24}$. A study conducted locally in $1997^{25}$ reported the etiology of neonatal conjunctivitis in 102 children. They obtained isolates of C. trachomatis in $33 \%$ of the cases,
Table 5. Systemic antibiotic therapy used in neonatal conjunctivitis $(n=69)^{*}$

\begin{tabular}{|l|c|c|}
\hline Systemic treatment & Total & $\%$ \\
\hline Ampicillin IV & 29 & 29 \\
\hline Amikacin IV & 18 & 18 \\
\hline Ampicillin/amikacin IV & 14 & 14 \\
\hline Azithromycin IV & 8 & 8 \\
\hline Piperacillin/tazobactam IV & 7 & 7 \\
\hline Ceftriaxone IV & 7 & 7 \\
\hline Ampicillin/gentamicin IV & 7 & 7 \\
\hline Clarithromycin IV & 2 & 2 \\
\hline Vancomycin IV & 2 & 2 \\
\hline Cefotaxime IV & 2 & 2 \\
\hline Ceftriaxone IV & 1 & 1 \\
\hline Ampicillin/cefepime IV & 1 & 1 \\
\hline Oxymetazoline IV & 1 & 1 \\
\hline Cefazolin IV & 1 & 1 \\
\hline Clarithromycin IV & 1 & 1 \\
\hline Total & 101 & 100 \\
\hline * patient could receive more than one IV antibiotic. & & \\
\hline IM: intramuscular; IV: intravenous. & & 7 \\
\hline
\end{tabular}

Table 6. Systemic antibiotic therapy used in neonatal conjunctivitis without systemic disease $(n=21)$

\begin{tabular}{|l|c|c|}
\hline Systemic treatment & Total & $\%$ \\
\hline Azithromycin/ceftriaxone & 7 & 33 \\
\hline Amikacin & 4 & 19 \\
\hline Ampicillin/amikacin & 3 & 14 \\
\hline Ampicillin & 2 & 10 \\
\hline Cefotaxime & 2 & 10 \\
\hline Piperacillin/tazobactam & 2 & 10 \\
\hline Ceftriaxone & 1 & 4 \\
\hline Total & 21 & 100 \\
\hline
\end{tabular}

H. influenzae in $18 \%$ and S. aureus in $15 \%$. Analyzing these results it can be considered that, although $\mathrm{C}$. trachomatis was the first cause of NC in the last years of the twentieth century, skin and airways-related microorganisms (non-gonococcal) already began to have an important place. 
Table 7. Topical antibiotic therapy used in neonatal conjunctivitis $(n=69)$

\begin{tabular}{|l|c|c|}
\hline Topical treatment & Total & $\%$ \\
\hline Sulfacetamide & 46 & 67 \\
\hline Gentamicin & 16 & 23 \\
\hline Ciprofloxacin & 3 & 4 \\
\hline Tobramycin & 2 & 3 \\
\hline Moxifloxacin & 2 & 3 \\
\hline Total & 69 & 100 \\
\hline
\end{tabular}

Most studies conducted in recent decades agree that there has been a change in the microbial etiology of $\mathrm{NC}^{10,11,15,18,24-27}$, from microorganisms acquired through the birth canal ( $\mathrm{N}$. gonorrhoeae and $\mathrm{C}$. trachomatis) to microorganisms of the skin and upper respiratory tract ${ }^{10,28}$.

The agents most frequently found in this study were of non-gonococcal origin: S. epidermidis $(28.9 \%$ of cases), S. aureus (17.39\% of cases) and $\mathrm{H}$. influenzae (13.04\% of cases). Although S. epidermidis has been considered as saprophytic flora and its pathogenic role is not entirely clear, it is suggested that the combination of specific conditions of the newborn (epidermal structure, a neonatal immune system still immature and the inappropriate use of antibiotics) could cause less virulent bacteria to become pathogenic ${ }^{29}$.

In another recent study, also conducted in South Korea and published in 2017, they did not find any cases of infection with $\mathrm{C}$. trachomatis or N. gonorrhoea, and the main isolated causative agents were Staphylococcus sp. ${ }^{10}$. These results ${ }^{18}$ are very similar to those obtained in our study, where non-gonococcal bacteria predominated, and we did not identify any positive isolates for $\mathrm{N}$. gonorrhoeae or $\mathrm{C}$. trachomatis.

In more than $50 \%$ of cases, a risk factor clearly related to a higher prevalence of these microorganisms was not found; however, UTI was the most frequent peripartum infection. No maternal vaginal infection by gonococcus or chlamydia was reported, which could indicate that in our environment there are adequate standards in maternal prenatal care, similar to those described in developed countries ${ }^{30}$.

The risk factors related to bacterial NC due to $S$. epidermidis and S. aureus were UTI, PROM and PBS. Different studies have shown similar results, meaning that these risk factors must be prevented, identified and treated ${ }^{5,31}$. However, no risk factor was identified in more than $50 \%$ of cases (Table 1).

Sulfacetamide and gentamicin were the most frequently used topical antibiotics. Systemically, it was ampicillin and amikacin; however, most of these patients had an associated systemic disease (sepsis), therefore, it is not possible to determine whether the systemic antibiotic was chosen based on the patient's underlying disease or the presence of NC. For this reason, an analysis of patients with NC and without systemic disease was performed. In this group of patients, azithromycin and ceftriaxone were the most commonly used systemic antibiotics. This demonstrates that broad-spectrum antibiotics targeted for more aggressive microorganisms (C. trachomatis and $\mathrm{N}$. gonorrhoeae) are still being used, although currently this agents are the least frequent, increasing the risk of developing antibiotic resistance.

From the results obtained in this study, it could be considered that in cases of NC without associated systemic infection, traditional topical antibiotics, such as gentamicin, tobramycin and sodium sulfacetamide, are an adequate option, since it has been shown that these skin and environment-related microorganisms have a less aggressive behavior in the eye and a minimal risk of producing systemic and local complications $\mathbf{s}^{5,10}$.

For the Staphylococcus group, responsible for about $50 \%$ of NC in our study, there was a resistance to oxacillin in $26 \%$ and to tetracyclines in $15 \%$, lower than that reported in other latitudes - up to $83.7 \%$ to methicillin ${ }^{10}$.

Our study has several limitations. First, the special cultures in Thayer Martin medium for N. gonorrhoeae and specific tests for $\mathrm{C}$. trachomatis were not performed in all patients, which may be associated with a bias in the results. The prospective evaluation conducted between March and November 2018 sought to reduce this bias. Additionally, the conduction of the study in a single center of very high complexity, limits its external validity. However, similar findings were obtained from other regions of the world, which diminishes this possibility.

\section{Conclusion}

The epidemiological profile of NC has changed, not only in our environment but worldwide. This leads us to face another type of non-gonococcal microorganisms (S. epidermidis and $\mathrm{S}$. aureus) that fortunately are not associated with serious complications as the ones observed with gonococcal microorganisms. The main 
route of infection in recent times is considered to be the skin and the respiratory tract, while in the past it was the birth canal. Therefore, the prevalence of NC should decrease with proper hand washing before coming into contact with neonates.

At the moment, the recommendation is to use traditional topical antibiotics, such as tobramycin and sulfacetamide, for cases of NC without associated systemic disease, and for cases of NC with systemic infection, the choice of systemic antibiotic will depend on the type of concomitant infection. Despite the emergence of commensal microorganisms of the skin and the environment, for all cases, cultures of aerobic bacteria, N. gonorrhoeae and $\mathrm{C}$. trachomatis should be requested, and the treatment should be guided according to the isolates obtained.

The decrease in the prevalence of gonococcal microorganisms and chlamydia in NC has been achieved with the screening of infections in the mother, the identification of risk factors (such as UTI, PROM and PBS), improvements in the quality of prenatal care and antibiotic prophylaxis in the newborn. All of these measures have changed the landscape of NC by reducing the blindness rates that were high in the past.

\section{Conflicts of interest}

The authors declare no conflicts of interest.

\section{Ethical disclosures}

Protection of human and animal subjects. The authors declare that no experiments were performed on humans or animals for this study.

Confidentiality of data. The authors declare that they have followed the protocols of their Institution

on the publication of patient data.

Right to privacy and informed consent. Informed consent collection was not required as the study was classified without risk and information was obtained from secondary sources.

\section{References}

1. Hammerschlag MR. Chlamydial and Gonococcal Infections in Infants and Children. Clin Infect Dis. 2011;53(suppl_3):S99-102.

2. Shahid E, Shaikh A, Aziz S, Rehman A. Frequency of Ocular Diseases in Infants at a Tertiary Care Hospital. Korean J Ophthalmol KJO. 2019;33(3):287-93.

3. Gilbert C, Foster A. Childhood blindness in the context of VISION 2020-the right to sight. Bull World Health Organ. 2001;79(3):227-32.
4. Cortés VR, Hernández R. Enfermedad infecciosa neonatal y gérmenes patógenos en un hospital de tercer nivel. (Spanish). Bol Med Hosp Infant Mex. 2006;63:S33-4.

5. Mohammed A, Ibrahim M, Mustafa A, Ihesiulor U. Maternal risk factors for neonatal conjunctivitis in Aminu Kano Teaching Hospital, Kano, Nigeria. Niger J Basic Clin Sci. 2013;10(2):60.

6. Krohn MA, Hillier SL, Bell TA, Kronmal RA, Grayston JT. The Bacterial Etiology of Conjunctivitis in Early Infancy. Am J Epidemiol. 1993;138(5):326-32.

7. Palafox SKV, Jasper S, Tauber, Allyson D, Foster SC. Ophthalmia Neonatorum. J Clin Exp Ophthalmol [Internet]. 2010;2:119el 27 de diciembre de 2010 [citado el 28 de diciembre de 2017];2(1). Disponible en: https://www. omicsonline.org/ophthalmia-neonatorum-2155-9570.1000119.php?aid=1094

8. Zikic A, Schünemann H, Wi T, Lincetto O, Broutet N, Santesso N. Treatment of Neonatal Chlamydial Conjunctivitis: A Systematic Review and Meta-analysis. J Pediatr Infect Dis Soc. 2018;7(3):e107-15.

9. Afjeiee SA, Tabatabaei SR, Fallah F, Shiva F, Zanjani NT, Fard AT, et al. A microbiological study of neonatal conjunctivitis in two hospitals in Tehran, Iran. Asian Pac J Trop Dis. 2013;3(6):429-33.

10. Pak KY, Kim SI, Lee JS. Neonatal Bacterial Conjunctivitis in Korea in the $21^{\text {st }}$ Century. Cornea. 2017;36(4):415-8.

11. Alexandre I, Cortes N, Justel M, Fernández I, Ortíz de Lejarazu R, Pastor JC The value of simple microbiological studies for on-site screening of acute neonatal conjunctivitis in Angola. J Ophthalmic Inflamm Infect. 2014;4(1):1.

12. Kara M, Kıvanç SA, Olcaysü OO, Akova Budak B, Özmen AT, Kıvanç M, et al. The newborn conjunctival flora at the post delivery 24 hours. J Curr Ophthalmol. 2018;30(4):348-52.

13. Rodríguez Gazquez M de los Á, Correa Muñoz E, Ospina Ospina S, Giraldo Jiménez C. Etiología bacteriana de la conjuntivitis neonatal. Metrosalud. Medellín, 1994. Colombia Medica. 1997;28(2):58-61.

14. Trujillo H, Restrepo C, Correa A, Robledo C, Harry N, Mejía GI. Conjuntivitis por Chlamydia trachomatis en recién nacidos y lactantes. Med UPB. 1989;8(1):27-32.

15. Schaller UC, Klauss V. Is Credé's prophylaxis for ophthalmia neonatorum still valid? Bull World Health Organ. 2001;79(3):262-3.

16. Mallika P, Asok T, Faisal H, Aziz S, Tan A, Intan G. Neonatal Conjunctivitis - a Review. Malays Fam Physician Off J Acad Fam Physicians Malays. 2008;3(2):77-81

17. Gul SS, Jamal M, Khan N. Ophthalmia neonatorum. J Coll Physicians Surg--Pak JCPSP. 2010;20(9):595-8.

18. McAnena L, Knowles SJ, Curry A, Cassidy L. Prevalence of gonococcal conjunctivitis in adults and neonates. Eye Lond Engl. julio de 2015;29(7):875-80.

19. Nsanze H, Dawodu A, Usmani A, Sabarinathan K, Varady E. Ophthalmia neonatorum in the United Arab Emirates. Ann Trop Paediatr. 1996; 16(1):27-32

20. Nishida H, Risemberg HM. Silver nitrate ophthalmic solution and chemical conjunctivitis. Pediatrics. 1975;56(3):368-73.

21. Armstrong JH, Zacarias F, Rein MF. Ophthalmia neonatorum: a chart review. Pediatrics. 1976;57(6):884-92.

22. Laga M, Nzanze H, Brunham R, Maitha G, D'Costa L, Mati JK, et al. Epidemiology of ophthalmia neonatorum in Kenya. The Lancet. 1986; 328(8516):1145-9.

23. Kim BL, Choi TH, Lee HB. The Neonatal Conjunctivitis. J Korean Ophthalmol Soc. 1997;38(9):1537-44.

24. Di SB, Mirta DH, Janer M, Rodríguez MF, Sauka D, Magariños F, et al. Incidence of Chlamydia trachomatis and other potential pathogens in neonatal conjunctivitis. Int J Infect Dis IJID Off Publ Int Soc Infect Dis. 2001;5(3):139-43.

25. Rodríguez Gazquez M de los Á, Correa Muñoz E, Ospina Ospina S, Giraldo Jiménez C. Etiología bacteriana de la conjuntivitis neonatal. Colomb Médica [Internet]. 1997 [citado el 13 de noviembre de 2017];28(2). Disponible en: http://www.redalyc.org/resumen.oa?id=28328202.

26. Honkila M, Renko M, Ikäheimo I, Pokka T, Uhari M, Tapiainen T. Aetiology of neonatal conjunctivitis evaluated in a population-based setting. Acta Paediatr Oslo Nor 1992. 2018;107(5):774-9.

27. Kokou V, Nidain M, Kassoula NB, Kwassi F-A, Meba B, Patrice BK [Neonatal conjunctivitis in the district of Glidji in Southern Togo: a cross sectional study about 159 new-borns]. Pan Afr Med J. 2016;24:42.

28. Satpathy G, Behera HS, Ahmed NH. Chlamydial eye infections: Current perspectives. Indian J Ophthalmol. 2017;65(2):97-102.

29. Tang S, Li M, Chen H, Ping G, Zhang C, Wang S. A chronological study of the bacterial pathogen changes in acute neonatal bacterial conjunctivitis in southern China. BMC Ophthalmol. 2017;17(1):174

30. Foster A, Klauss V. Ophthalmia neonatorum in developing countries. N Engl J Med. 1995;332(9):600-1

31. Isenberg SJ, Apt L, Wood M. The influence of perinatal infective factors on ophthalmia neonatorum. J Pediatr Ophthalmol Strabismus. 1996; 33(3):185-8 